American Journal of Agricultural and Biological Sciences 3 (4): 666-668, 2008

ISSN 1557-4989

(C) 2008 Science Publications

\title{
Effect of Plant Density on Flowering Date, Yield and Quality Attribute of Bush Beans (Phaseolus Vulgaris L.) under Center Pivot Irrigation System
}

\author{
Samih Abubaker \\ Department of Plant Production and Protection, \\ Al Balqa`Applied University, Salt, Jordan
}

\begin{abstract}
This research evaluates six different planting densities $(10 * 30,20 * 30,30 * 30,40 * 30,50 * 30$, $60 * 30$ ) of bean (Phaseolus Vulgaris L.), Bronco variety and their impacts on yield, earliness and quality attributes using Randomized Complete Block Design (RCBD) under central pivot irrigation system in the southern part of Jordan during 2007 growing season. Although, the highest planting density $(10 * 30 \mathrm{~cm})$ gave the highest percent of early yield $(93 \%)$ in comparison to the total yield it was among the lowest yielding ability and tended to give pods with lower N,P,K and protein contents. The highest yields were obtained by $20 * 30$ and $30 * 30 \mathrm{~cm}$ planting densities with 73 and $71 \%$ respectively of early yield related to the total yield. Stem diameter, pod dry weight as well as protein and mineral contents tended to be higher under the lower planting densities. The issue of this research seems to give clear perspectives to obtain high early yield with good enough quality under $20 * 30 \mathrm{~cm}$ bush bean under central pivot irrigation system in the desert of southern part of Jordan.
\end{abstract}

Key words: Beans, plant density, flowering date, yield

\section{INTRODUCTION}

Different planting densities demonstrated varied and inconstant effects on crop quality. However, Abubaker et al. ${ }^{[1]}$ found no significant effects of plant population on stem diameter and on time of flowering. $\mathrm{He}$ also mentioned constant significant superior yields of high plant populations over those of low plant population of plastic house beans. Never the less, $p$ content of the pods was increased as planting density decreased, while no significant effects were detected for $\mathrm{N}, \mathrm{K}$ and protein contents of the bean pods.

Fresh bean is an important horticultural crop grown in Jordan. In the southern part of the country, were central pivots are spread, no supporting research, to my knowledge has been done on beans. Stofella et al. ${ }^{[13]}$ reported that more stem hypocotyls diameter of bean plants were occurred with increasing within row spacing. Variation of plant population affects total bean yields ${ }^{[8,9,2]}$. It was indicated by ${ }^{[9]}$ that bean yield was increased as that densities increased. Higher planting densities gave $7-48 \%$ higher bean yields in seven out of nine fields experiments ${ }^{[6]}$ Snap bean yield increased at high planting density with 7-10 days earliness ${ }^{[3]}$. The aim of this study is to evaluate the influence of different bean densities on yield and quality under central pivot irrigation system in the desert area of Jordan.

\section{MATERIALS AND METHODS}

Seed of commercial bush bean (Phaseolus Vulgaris L.) variety Bronco from Asgrow seed company were directly sown at 5-6 $\mathrm{cm}$ depth at Rum Agricultural Farms in the southern part of Jordan under central pivot irrigation system on July, 20, 2007. The study had concluded the first harvest on September, 13.2007 and the last harvest was concluded on October, 2.2007. A Randomized Complete Block Design (RCBD) with three replicates and six plant densities as treatments were used. Each treatment consisted of three rows three meters long and thirty $\mathrm{cm}$ apart with plant spaced 10 , $20,30,40,50$ and $60 \mathrm{~cm}$ within the row for the different treatments. One day after planting Stomp herbicide was applied at a rate of $2 \mathrm{~L} \mathrm{ha}^{-1}$ to keep weeds under control. At the end of the first week of germination hills were thinned to one plant. Irrigation was applied uniformly and whenever needed through centre pivot system. Compound soluble fertilizers of a total of $80 \mathrm{~kg} \mathrm{ha}^{-1}$ of nitrogen, $100 \mathrm{~kg} \mathrm{ha}^{-1}$ of phosphorus and $100 \mathrm{~kg} \mathrm{ha}^{-1}$ of potassium were distributed at three days interval with the irrigation water system through out the season starting one week after emergence. The harvest season on immature pod stage basis was commenced on September, 12 for the early harvest and on October, 2 for the late harvest season. Fresh weights were recoded directly. Data of 
Am. J. Agri. \& Biol. Sci., 3 (4): 666-668, 2008

average pod weight was studied by a thirty pod random sample taken from every treatment. Number of days for $50 \%$ of plants to be flowered by daily check of flowers on the plants was estimated. Plant growth, stem diameter at the hypocotyls area and dry matter content of the pods were calculated after oven drying of the samples at $70^{\circ} \mathrm{C}$ to a constant weight. Chemical analysis of $\mathrm{N}, \mathrm{P}, \mathrm{K}$ and protein contents were determinate on dry basis of the pods. For the determination of total nitrogen, the Kjeldhal procedure [2] was generally employed. Protein content was estimated by multiplying the total nitrogen content by a constant factor of $6.25^{[4]}$. Available phosphorus was measured by Spectrophotometer ${ }^{[10]}$. Flame photometer according to Knudsen ${ }^{[5]}$ measured available potassium. Data obtained was statistically analyzed as for the randomized complete block design and mean separation was conducted following the Duncan's Multiple Range Test using SAS, according to Steel and Torrie ${ }^{[11]}$.

\section{RESULTS AND DISCUSSION}

Effect on yield earliness and quality attributes: The highest planting density $(10 * 30 \mathrm{~cm})$ was among the lowest yielding treatments (Table 1). This could by due to the high competition for water and minerals. The highest early and total yields of beans were obtained under the $20 * 30\left(9.14\right.$ and $\left.12.55 \mathrm{t} \mathrm{ha}^{-1}\right)$ respectively and $30 * 30 \mathrm{~cm}\left(8.59\right.$ and $\left.12.09 \mathrm{t} \mathrm{ha}^{-1}\right)$ respectively, moreover, total yields obtained from the two densities were statistically similar. The lowest yielding early and total yield was given from the lowest density $(60 * 30$ $\mathrm{cm}$ ) treatment which produced $4.48 \mathrm{t} \mathrm{ha}^{-1}$ early in the season and a total of $6.98 \mathrm{t} \mathrm{ha}^{-1}$. These results are similar to those of ${ }^{[8,12]}$ on bean crop under various planting densities. Constant and general tending towards higher values of average pod weight, pod dry weight and stem diameter (Table 2) by using lower planting densities, this could be due to lower number of plants per experiments unit area resulting in more water and soil nutrients pool per plant which consequently contributed to greater photosynthesis through larger stem diameter per single plant. This is coincided with ${ }^{[13]}$ who reported more portions of photosynthates to be Tran located to the beans of larger stem diameter. However, number of days for $50 \%$ of plants to be flowered (Table 2) was significantly affected by different planting densities. Lower planting densities needed higher number of days for blooming. This could be related to the supportive effects of more available fertilizers to lower number of plants per unit area which permitted building of more vigorous growth that
Table 1: Effect of planting density on early, late and total yield of bush beans under center pivot irrigation system

\begin{tabular}{llll}
\hline Treatments & $\begin{array}{l}\text { Early yield } \\
\left(\mathrm{T} \mathrm{ha}^{-1}\right)\end{array}$ & $\begin{array}{l}\text { late yield } \\
\left(\mathrm{T} \mathrm{ha}^{-1}\right)\end{array}$ & $\begin{array}{l}\text { Total yield } \\
\left(\mathrm{T} \mathrm{ha}^{-1}\right)\end{array}$ \\
\hline 1 & $8.06 \mathrm{C}$ & $0.63 \mathrm{E}$ & $8.69 \mathrm{BC}$ \\
2 & $9.14 \mathrm{~A}$ & $3.41 \mathrm{AB}$ & $12.55 \mathrm{~A}$ \\
3 & $8.59 \mathrm{~B}$ & $3.5 \mathrm{~A}$ & $12.09 \mathrm{~A}$ \\
4 & $6.45 \mathrm{D}$ & $2.84 \mathrm{C}$ & $9.29 \mathrm{~B}$ \\
5 & $5.37 \mathrm{E}$ & $3.1 \mathrm{BC}$ & $8.47 \mathrm{C}$ \\
6 & $4.48 \mathrm{~F}$ & $2.50 \mathrm{D}$ & $6.98 \mathrm{D}$ \\
LSD & 0.4657 & 0.3219 & 0.7659 \\
\hline
\end{tabular}

Treatments $1,2,3,4,5,6=10 * 30,20 * 30,30 * 30,40 * 30,50 * 30$, $60 * 30 \mathrm{~cm}$ respectively

Table 2: Effect of planting density on flowering date and some flowering attributes of bush beans under center pivot irrigation system

\begin{tabular}{lllll}
\hline & $\begin{array}{l}\text { No. of days for } \\
50 \% \text { of plants } \\
\text { to be flowered }\end{array}$ & $\begin{array}{l}\text { Stem } \\
\text { diameter } \\
(\mathrm{mm})\end{array}$ & $\begin{array}{l}\text { Pod fresh } \\
\text { weight }(\mathrm{g})\end{array}$ & $\begin{array}{l}\text { Pod dry } \\
\text { weight } \\
(\%)\end{array}$ \\
\hline 1 & $32.00 \mathrm{E}$ & $3.54 \mathrm{D}$ & $7.300 \mathrm{C}$ & $8.10 \mathrm{D}$ \\
2 & $34.66 \mathrm{D}$ & $5.19 \mathrm{C}$ & $9.73 \mathrm{~B}$ & $9.29 \mathrm{C}$ \\
3 & $35.00 \mathrm{CD}$ & $5.20 \mathrm{C}$ & $9.70 \mathrm{~B}$ & $9.46 \mathrm{C}$ \\
4 & $35.33 \mathrm{C}$ & $5.47 \mathrm{~B}$ & $10.00 \mathrm{~A}$ & $9.49 \mathrm{C}$ \\
5 & $37.66 \mathrm{~B}$ & $6.11 \mathrm{~A}$ & $10.10 \mathrm{~A}$ & $10.43 \mathrm{~B}$ \\
6 & $38.33 \mathrm{~A}$ & $6.17 \mathrm{~A}$ & $10.20 \mathrm{~A}$ & $10.80 \mathrm{~A}$ \\
LSD & 0.6643 & 0.1238 & 0.2341 & 0.288 \\
\hline
\end{tabular}

Treatments $1,2,3,4,5,6=10 * 30,20 * 30,30 * 30,40 * 30,50 * 30$, $60 * 30 \mathrm{~cm}$ respectively

Table 3: Effect of planting density on N, P, K and protein content of bush beans under center pivot irrigation system

\begin{tabular}{lllll}
\hline \multicolumn{2}{l}{ Treatments $\mathrm{N}(\%)$} & $\mathrm{P}(\%)$ & $\mathrm{K}(\%)$ & Protein $(\%)$ \\
\hline 1 & $2.90 \mathrm{C}$ & $0.31 \mathrm{~B}$ & $3.00 \mathrm{C}$ & $18.12 \mathrm{C}$ \\
2 & $3.32 \mathrm{~B}$ & $0.34 \mathrm{AB}$ & $3.40 \mathrm{~B}$ & $20.75 \mathrm{BC}$ \\
3 & $3.35 \mathrm{AB}$ & $0.34 \mathrm{AB}$ & $3.43 \mathrm{~B}$ & $20.94 \mathrm{AB}$ \\
4 & $3.44 \mathrm{AB}$ & $0.37 \mathrm{~A}$ & $3.51 \mathrm{AB}$ & $21.50 \mathrm{AB}$ \\
5 & $3.50 \mathrm{AB}$ & $0.37 \mathrm{~A}$ & $3.60 \mathrm{~A}$ & $21.88 \mathrm{AB}$ \\
6 & $3.56 \mathrm{~A}$ & $0.39 \mathrm{~A}$ & $3.61 \mathrm{~A}$ & $22.25 \mathrm{~A}$ \\
LSD & 0.2166 & 0.0532 & 0.1217 & 2.7547 \\
\hline
\end{tabular}

Treatments $1,2,3,4,5,6=10 * 30,20 * 30,30 * 30,40 * 30,50 * 30$, $60 * 30 \mathrm{~cm}$ respectively

resulted in higher number of days for blooming of the bean plants ${ }^{[1]}$.

Effect on chemical properties of the pods: Nitrogen, $\mathrm{P}, \mathrm{K}$ and protein contents of the bean pods on dry basis were significantly affected by different planting densities under the conditions of this research. Decreasing planting density showed increased and constant values of $\mathrm{N}, \mathrm{P}, \mathrm{K}$ and protein contents of the bean pods (Table 3 ). This could be due to the lower competition for nutrients by the lower number of plants per unit area; this was agreed upon by the results of ${ }^{[7]}$ who found higher N, P and K in bean leaves of lower density planting compared to those of higher density. 
Am. J. Agri. \& Biol. Sci., 3 (4): 666-668, 2008

\section{CONCLUSION}

Higher yields were obtained by $20 * 90 \mathrm{~cm}$ densities. Protein and mineral contents of beans tended to be higher under the wider plant spacing without significant differences among $20 * 90,30 * 90,40 * 90$, $50 * 90 \mathrm{~cm}$ planting densities.

\section{ACKNOWLEDGEMENT}

This study was supported by the administration of Rum Agricultural Farms.

\section{REFERENCES}

1. Abubaker S., Kasrawi and Aburayan, 2007. Effect of conventional, organic and GAP on nitrate content of plastic house beans. Acta Horticulture, 741: 35-40. http://www.actahort.org/books/741/741 4.htm.

2. Bremner, J.M. and C.G. Mulvancy, 1982. TotalNitrogen. In: Methods of Soil Analysis, Part 2, Chemical and Microbiological Properties, Miller, R.H. and D.R. Keeney (Eds.). American Society of Agronomy, Inc., Publisher, Madison, Wisconsin, USA, pp: 595-624. ISBN: 10:089118810X

3. Crothers, S. and D. Westermann, 1976. Plant population effects on the seed yield of phaseolus vulgaris L. Agron. J., 68: 958-960. http://agron. scijournals.org/cgi/content/abstract/68/6/958.

4. Hojjati, S., 1976. Amino acid patterns of kidney beans grown under different $\mathrm{S}$ and $\mathrm{K}$ regimes. Agronomy J., 68: 668-671. http://agron.scijournals. org/ cgi/content/abstract/68/4/668.

5. Knudsen, D., G.A. Peterson and P.F. Pratt, 1982. Lithium, Sodium and Potassium. In: Methods of Soil Analysis, Part 2, Chemical and Microbiological Properties, Miller, R.H. and D.R. Keeney (Eds.). American Society of Agronomy, Inc., Publisher, Madison, Wisconsin, USA. pp: 410-435. ISBN10:089118810X

6. Kueneman, E., R. Sandsted, D. Wallace, A. Bravo and H. Wien, 1979. Effect of plant arrangements and densities on yield of dry beans. Agron. J., 71: 419-424. http://agron.scijournals.org/cgi/ content/abstract/71/3/419

7. Mack, H.J., 1983. Fertilize and plant density effects on yield performance and leaf nutrient concentration of bush snap beans. J. Am. Soc. Hort. Sci., 108: 574-578. http://www.fao.org/ agris/search/display.do;jsessionid=B71F3E4E9C4 A6772174255F8FE94BA4F? $\mathrm{f}=. / 1984 / \mathrm{v} 1004 / \mathrm{US} 82$ 89176.xml;US8289176.
8. Mack, H.J. and D. Hatch, 1968. Effect of plant arrangement and population density on yield of bush snap beans. Am. Soc. Hort. Sci., 92: 418-425. http://66.102.1.104/scholar?hl=ar\&lr=\&q=cache:za iQRQ2bgw0J:orton.catie.ac.cr/cgi-bin/wxis.exe/\% 3FIsisScript\%3DCATALCO.xis\%26method\%3Dp ost $\% 26$ formato $\% 3 \mathrm{D} 2 \% 26$ cantidad $\% 3 \mathrm{D} 1 \% 26$ expre sion\%3Dmfn\%3D075100+Effect+of+plant+arrang ement + and + population + density + on + yield + of + bus $\mathrm{h}+$ snap+beans

9. Morgade, L. and R. Willey, 2003. Effect of plant population and nitrogen fertilizer on yield and efficiency of maize/bean intercropping. Pesq. Agropec. Bras. Brasilia, 38: 1257-1264. DOI: 10.1590/S0100-204X2003001100002.

10. Olsen, S.R. and L.E. Sommers, 1982. Phosphorus. In: Methods of Soil Analysis, Part 2, Chemical and Microbiological Properties, Miller, R.H. and D.R. Keeney (Eds.). American Society of Agronomy, pp: 48o-507. Income, Publisher, Madison, Wisconsin, USA. ISBN: 10:089118810X

11. Steel and Torrie, 1980. Principles and procedures of statistics. pp: 196-215. McGraw-Hill, Inc. ISBN10: 1428814221 ISBN13: 9781428814226

12. Smittle, D.A., 1976. Response of snap bean to irrigation, nitrogen fertilization and plant population. J. Am. Soc. Hort. Sci., 101: 37-40. http://66.102.1.104/scholar?hl=ar\&lr=\&q=cache:7 uVgLI6Q8jUJ:orton.catie.ac.cr/cgi-bin/wxis.exe/\% 3FIsisScript\%3DCATALCO.xis\%26method\%3Dp ost $\% 26$ formato\%3D2\%26cantidad\%3D1\%26expre sion\%3Dmfn\%3D075176+author:\%22Smittle\%22 +intitle:\%22Response+of+snap+bean+to+irrigatio $\mathrm{n},+$ nitrogen $+. . \% 22+$

13. Stoffeila, P.J., R.F. Sandsted, R.W. Zobel and W.L. Hymes, 1981. Root Morphological Characteristics of kidney beans as influenced by within-row spacing. HortScience, 16: 543-545. http://64.233. 183.104/search?q=cache:PqfkCgNX218J:orton.cati e.ac.cr/cgi-bin/wxis.exe/\%3FIsisScript\%3DCATA LCO.xis\%26method\%3Dpost $\% 26$ formato\%3D2\% 26cantidad\%3D1\%26expresion\%3Dmfn\%3D0707 $88+$ Root+Morphological + Characteristics + of + kidn ey+beans+as+influenced+by+within-row+spacing $\& \mathrm{hl}=\mathrm{ar} \& \mathrm{ct}=\mathrm{clnk} \& \mathrm{~cd}=4 \& \mathrm{gl}=$ jo 